\title{
A AUTONOMIA PRIVADA NA CESSÃO DE DIREITOS HEREDITÁRIOS E 0 DIREITO DE PREFERÊNCIA
}

\section{PRIVATE AUTONOMY IN THE ASSIGNMENT OF HEREDITARY RIGHTS AND THE RIGHT OF FIRST REFUSAL}

\author{
Leonardo Estevam de Assis Zanini ${ }^{1}$ \\ Odete Novais Carneiro Queiroz ${ }^{2}$
}

\begin{abstract}
Resumo: $O$ presente artigo analisa o regime jurídico da cessão de direitos hereditários, assunto de grande relevância prática no direito brasileiro. A matéria não era diretamente prevista pelo Código Civil de 1916, o que gerava divergências entre os estudiosos. Trata-se de pesquisa que utiliza metodologia descritiva e dedutiva, baseada fundamentalmente na investigação bibliográfica, jurisprudencial e legislativa. Para tanto, o texto estuda, em um primeiro momento, a indivisibilidade da herança e a responsabilidade dos herdeiros pelas dívidas hereditárias. Em seguida, passa-se ao exame do conceito, do objeto, dos requisitos, das condições e dos limites da cessão de direitos hereditários no Código Civil de 2002. Por fim, analisa-se o direito de preferência dos coerdeiros, que também passou a ser expressamente reconhecido pela legislação brasileira.
\end{abstract}

Palavras-chave: Direito das sucessões. Indivisibilidade da herança. Responsabilidade dos herdeiros. Cessão de herança. Direito de preferência.

Abstract: The present article analyses the legal regime of the assignment of inheritance rights, a matter of great practical relevance in Brazilian law. The matter was not directly regulated by the Civil Code of 1916, which generated divergences among scholars. This research uses descriptive and deductive methodology, based primarily on bibliographic, case law and legislative research. For such, the text studies, in a first moment, the indivisibility of the inheritance and the responsibility of heirs for inherited debts. Next, it examines the concept, object, requirements,

1 Livre-docente e doutor em direito civil pela USP. Pós-doutorado em direito civil pelo Max-Planck-Institut für ausländisches und internationales Privatrecht (Alemanha). Pós-doutorado em direito penal pelo Max-Planck-Institut für ausländisches und internationales Strafrecht (Alemanha). Doutorando em direito civil pela Albert-Ludwigs-Universität Freiburg (Alemanha). Mestre em direito civil pela PUC-SP. Bacharel em direito pela USP. Juiz Federal na Seção Judiciária de São Paulo. Professor Universitário (graduação e pós-graduação). Pesquisador do grupo Novos Direitos $\mathrm{CNPq} / \mathrm{UFSCar}$. Autor de livros e artigos publicados nas áreas de direito civil, direitos intelectuais e direito do consumidor. Foi bolsista da Max-Planck-Gesellschaft e da CAPES. Foi Delegado de Polícia Federal, Procurador do Banco Central do Brasil, Defensor Público Federal, Diretor da Associação dos Juízes Federais de São Paulo e Mato Grosso do Sul e Diretor Acadêmico da Escola de Formação e Aperfeiçoamento de Servidores da Justiça Federal em São Paulo.

2 Doutora e mestre em Direito Civil pela Pontifícia Universidade Católica de São Paulo - PUC-SP. Professora doutora, por concurso público, na graduação e pós-graduação da Faculdade de Direito da PUC-SP, onde leciona Direito Civil.

Revista Auditorium, Rio de Janeiro, v. 25, n. 52 p. 81-106, jul./out. 2021 
conditions, and limits of the assignment of inheritance rights under the Civil Code of 2002. Finally, the right of first refusal of the coheirs is analyzed, which is also expressly recognized by the Brazilian legislation.

Keywords: Law of succession. Indivisibility of inheritance. Responsibility of heirs. Assignment of inheritance. Right of first refusal.

Recebido em: 26/09/2021 Aceito para publicação em: 26/10/2021 


\section{INTRODUÇÃO}

A herança constitui um valor jurídico com evidente conteúdo patrimonial. Posicionando-se entre os bens jurídicos patrimoniais, a herança comporta circulação jurídica, podendo ser negociada por seu titular, mesmo antes da partilha, por meio de negócio jurídico denominado cessão de direitos hereditários ou cessão de herança.

A cessão de herança constitui um instituto jurídico amplamente utilizado no direito das sucessões. Sua relevância prática se deve ao fato de que muitas vezes representa a única forma de um herdeiro receber algum proveito em vida (FRANK; HELMS, 2018, p. 300), haja vista que muitos processos judiciais de inventário e partilha se arrastam por anos e anos nos tribunais. Apesar disso, até a entrada em vigor do Código Civil de 2002, a cessão de herança não era expressamente regulada pela legislação pátria, o que conduzia a inúmeras discussões na doutrina e na jurisprudência, particularmente no que toca à necessidade de escritura pública e de anuência dos coerdeiros.

Em função de sua importância na prática jurídica e considerando as vicissitudes que podem surgir quando da realização desse negócio jurídico rodeado por disposições especiais, não há dúvida que a cessão de herança demanda redobrada atenção do estudioso do direito civil. Assim sendo, a compreensão desse importante fenômeno jurídico sucessório requer, antes de seu estudo propriamente dito, o necessário e prévio entendimento acerca da indivisibilidade da herança e da responsabilidade dos herdeiros pelas dívidas hereditárias.

A partir do domínio desses elementos, reconhecendo-se que o monte hereditário é devolvido de forma unitária e indivisível, analisa-se o conceito, o objeto, os requisitos, as condições, a extensão e as responsabilidades que envolvem a cessão de herança. Em seguida, passa-se ao estudo do direito de preferência dos credores.

Ademais, vale notar que o presente estudo utiliza metodologia descritiva e dedutiva, baseada fundamentalmente na investigação bibliográfica, legislativa e jurisprudencial.

Revista Auditorium, Rio de Janeiro, v. 25, n. 52 p. 81-106, jul./out. 2021 


\section{PRINCÍPIO DA INDIVISIBILIDADE DA HERANÇA}

Em virtude de disposição legal, ocorrem num só momento a morte do titular do patrimônio, a abertura da sucessão e a transmissão da herança aos herdeiros (art. 1.784)3. Isso significa que a herança, como regra, transmite-se automaticamente aos sucessores no momento da morte do de cujus, passando a posse e a propriedade de todos os bens que compõem a herança a integrar 0 patrimônio dos sucessores ${ }^{4}$.

O princípio da indivisibilidade estabelece que até a partilha final da herança, o direito dos coerdeiros, quanto à propriedade e a posse da herança, será indivisível. Ainda que o de cujus tenha vários herdeiros, a herança defere-se como um todo unitário e indivisível, regulando-se pelas normas relativas ao condomínio (art. 1.791 e parágrafo único).

A indivisibilidade diz respeito à propriedade e à posse dos bens hereditários. Assim sendo, antes da realização da partilha, nenhum herdeiro tem a propriedade ou a posse exclusiva sobre um bem certo e determinado do acervo. Isso quer dizer que o herdeiro tem direito sobre uma parte ideal do acervo hereditário (MONTEIRO, 2016, p. 49).

Somente com a partilha é que se individualiza ou materializa o que cabe, concreta e objetivamente, a cada herdeiro (GOZZO; VENOSA, 2004, p. 56-57). A indivisão cessa, em regra, com o julgamento da partilha, a partir daí o direito de cada herdeiro ficará circunscrito aos bens do respectivo quinhão (art. 2.023).

\footnotetext{
${ }^{3} \mathrm{O}$ fato jurídico morte produzirá incontinenti seu efeito, qual seja, a passagem dos direitos e deveres do antecessor que morreu aos seus herdeiros sucessíveis (art. 1.784). A morte é pressuposto, é causa da mudança subjetiva da posição do de cujus nas suas relações jurídicas transmissíveis para seus herdeiros sobrevivos. E assim é por força da conhecida fórmula do droit de saisine, que se traduz nesse imediatismo da transferência da propriedade e da posse dos bens do morto aos seus herdeiros de modo a não permitir que o patrimônio do falecido fique acéfalo por qualquer momento. Até a morte essas relações jurídicas que formavam tal patrimônio tinham por sujeito o de cujus e no mesmo instante do seu passamento os herdeiros terão tal titularidade. A herança é passada como um todo unitário, indivisível, estabelecendo-se entre os coerdeiros o regime condominial até a partilha (art. 1.791).

${ }^{4}$ Também pode ocorrer, excepcionalmente, a transmissão da herança na data fixada em sentença que reconheça a morte presumida (HIRONAKA, 2003, p. 68).

Revista Auditorium, Rio de Janeiro, v. 25, n. 52 p. 81-106, jul./out. 2021
} 
A herança é então, tal qual o patrimônio, uma universalidade. Dessa maneira, sempre que pertencer a mais de uma pessoa, "não é suscetível de divisão em partes materiais enquanto permanecer como tal" (GOMES, 2015, p. 7).

Por conseguinte, em função da indivisibilidade da herança, considera-se ineficaz a cessão feita pelo coerdeiro, antes da partilha, de seu direito hereditário sobre qualquer bem da herança considerado singularmente (art. 1.793, § $2^{\circ}$ ).

\section{A INDIVISIBILIDADE DO DIREITO DOS COERDEIROS}

A herança é uma universalidade de direito (universitas juris). Trata-se de um complexo de relações jurídicas, que é considerado pela lei como uma unidade dotada de valor econômico (art. 91). Cuidando-se de uma universalidade, é certo que o direito dos herdeiros à posse e à propriedade da herança é indivisível. Somente com a realização da partilha é que serão determinados os bens que comporão o quinhão de cada coerdeiro (art. 1.791, parágrafo único).

Ao mesmo tempo em que a indivisibilidade é imposta pela lei e dura até a sentença de partilha (parágrafo único do art. 1.791), também previu o legislador que se aplicam à herança, no que couber, as regras atinentes ao condomínio. Assim sendo, o herdeiro, dada a sua condição de condômino, é titular apenas de uma parte ideal do espólio, uma vez que seu quinhão somente se individuará por ocasião da partilha. Isso equivale a dizer que o herdeiro pode alienar a terceiro sua parte indivisa. Também pode alienar uma parte de seu quinhão. Não pode, jamais, alienar um bem específico que componha o acervo patrimonial ou hereditário, visto que tal bem é insuscetível de ser alienado por um dos condôminos sem o assentimento dos demais (MONTEIRO, 2016, p. 50).

Se todos os coproprietários desejarem fazer a venda de um determinado bem, isso somente é possível quando é a comunidade que realiza a alienação, haja vista a existência de propriedade em mão comum entre os herdeiros (Gesamtshandsgemeinschaf) ${ }^{5}$. Com isso, o preço recebido, até ser dividido entre os

\footnotetext{
${ }^{5}$ A despeito do parágrafo único do art. 1.791 determinar que são aplicáveis as normas relativas ao condomínio, em realidade o que existe entre os coerdeiros é uma propriedade em mão comum, visto Revista Auditorium, Rio de Janeiro, v. 25, n. 52 p. 81-106, jul./out. 2021
} 
interessados, sub-roga-se no lugar da coisa vendida, com fundamento no princípio da sub-rogação real (VENOSA, 2019, p. 1547-1548).

Entretanto, ressalva deve ser feita em relação à sucessão em que há apenas um herdeiro. Em se tratando de herdeiro único, todos os bens da herança incorporam-se diretamente ao patrimônio do sucessor, podendo ser considerados individualmente, pelo que são singularmente passíveis de alienação (MAIA JÚNIOR, 2018, p. 230).

Ademais, em face da indivisibilidade, cada herdeiro tem a prerrogativa de reclamar a herança inteira, de quem quer que injustamente a possua, sem que essa pessoa possa se defender alegando o caráter parcial do direito do reivindicante. De fato, como a lei declarou indivisível o seu direito atinente à propriedade e à posse daquela universalidade, pode ele reclamá-la por inteiro, visto que a lei lhe dá legitimação para tanto (art. 1.825).

\section{RESPONSABILIDADE DOS HERDEIROS}

No direito romano, a responsabilidade do herdeiro pelas dívidas hereditárias era inicialmente ilimitada e absoluta. O sucessor não tinha como se livrar do dever de resgatar tais débitos. Mais do que uma sucessão patrimonial entre dois sujeitos, o herdeiro (heres) tomava o lugar do falecido na família, recebendo não somente o ativo e assumindo o passivo deixado pelo de cujus, mas passando a ser o responsável pela continuação da própria família, incluindo o culto dos deuses domésticos (APATHY; KLINGENBERG; PENNITZ, 2016. p. 71). Havia uma autêntica sucessão da posição jurídica do falecido. O patrimônio do herdeiro se confundia com o patrimônio do autor da herança, de modo que os credores deste passavam a ser credores daquele (POLETTO, 2013, p. 107).

Mais tarde, no ano de 531, Justiniano resolveu abrandar o rigorismo da matéria, permitindo que a aceitação pudesse ser feita sob benefício de inventário (beneficium inventarii), protegendo os herdeiros de um eventual superendividamento

que eles somente podem resolver conjuntamente os problemas relacionados à herança (WOLF; WELLENHOFER, 2019, p. 17).

Revista Auditorium, Rio de Janeiro, v. 25, n. 52 p. 81-106, jul./out. 2021 
do de cujus (KASER; KNÜTEL; LOHSSE, 2017, p. 438). A partir daí a confusão patrimonial não se operava desde logo, de modo que o herdeiro só aceitaria a sucessão que Ihe fosse devolvida se, após o inventário, verificasse que 0 ativo superava o passivo (NADER, 2016, p. 534).

Esse regime foi seguido pela maioria dos países. Também foi o sistema adotado pelo Brasil até a vigência do Código Civil de 1916, de maneira que o herdeiro aceitava a herança a benefício de inventário, resguardando-se em relação às dívidas do espólio, que seriam pagas pelas forças do acervo hereditário. Todavia, a partir da codificação de Clóvis Beviláqua, estabeleceu-se que a responsabilidade do herdeiro não excede as forças da herança (art. 1.587). Assim sendo, pela sistemática da codificação anterior, a aceitação se dava sempre a benefício de inventário, ou seja, somente seriam pagas pelos herdeiros as dívidas que não ultrapassassem o monte partilhado, uma vez que a responsabilidade do herdeiro era intra vires hereditatis (DINIZ, 2021, p. 85). E tal orientação foi também seguida pelo Código Civil de 2002 (art. 1.792) ${ }^{6}$ e pelo Código de Processo Civil de 2015 (art. 796)7.

Nessa senda, de acordo com o art. 1.792 do Código Civil, o herdeiro não responde por encargos superiores às forças da herança, o que explicita a existência de uma cláusula tácita de benefício de inventário no sistema jurídico brasileiro (FARIAS; ROSENVALD, 2020, p. 237). Com isso, a aceitação da herança é sempre, por força de lei, a benefício de inventário, não sendo mais necessária ressalva expressa. Ficam separados o patrimônio da herança e o patrimônio do herdeiro. As responsabilidades dos herdeiros restringem-se ao montante deixado pelo falecido, de sorte que o prejuízo pelo que não foi pago pela herança é assumido pelo credor (POLETTO, 2013, p. 106).

Em todo caso, no que toca aos encargos superiores às forças da herança, é necessário que o herdeiro prove a existência do excesso, salvo se houver inventário demonstrando o valor dos bens herdados. É que no inventário é feito o levantamento

\footnotetext{
${ }^{6}$ Art. 1.792 do Código Civil: "O herdeiro não responde por encargos superiores às forças da herança; incumbe-lhe, porém, a prova do excesso, salvo se houver inventário que a escuse, demonstrando o valor dos bens herdados".

7 Art. 796 do Código de Processo Civil: "O espólio responde pelas dívidas do falecido, mas, feita a partilha, cada herdeiro responde por elas dentro das forças da herança e na proporção da parte que Ihe coube".

Revista Auditorium, Rio de Janeiro, v. 25, n. 52 p. 81-106, jul./out. 2021
} 
do patrimônio do falecido, das relações jurídicas de natureza econômica, dos bens e vantagens, bem como das obrigações e débitos que ele deixou. Havendo inventário, as dívidas são da herança, que responde por elas (art. 1.997). Por outro lado, na hipótese de inexistência de inventário, o herdeiro deverá comprovar que o valor recebido é inferior à dívida.

O herdeiro pode, entretanto, renunciar ao benefício de inventário, aceitando assumir todos os débitos do falecido, ainda que superiores ao ativo da herança. Trata-se de mera liberalidade, que pode ter motivação de ordem moral, por não querer o sucessor deixar os débitos do de cujus sem quitação (GONÇALVES, 2019, p. 91).

Por conseguinte, existindo inventário, dispensado está o herdeiro de comprovar os encargos superiores às forças da herança (art. 1.792, segunda parte). Feito o inventário, serão partilhados os bens ou valores que restarem depois de pagas as dívidas, isto é, apurado o ativo e compensado o passivo, o restante será entregue aos herdeiros na proporção de suas quotas hereditárias (HIRONAKA, 2003, p. 71).

\section{A CESSÃO DE DIREITOS HEREDITÁRIOS}

A cessão de direitos hereditários já era admitida no direito romano, mas somente a partir do Código Civil francês que a matéria ganhou tratamento particular, ao se prever, em seu art. 780, a possibilidade de doação ou venda da herança (LEITE, 2003, p. 75).

O Código Civil de 1916 não regulava expressamente a cessão de direitos hereditários. A matéria era tratada apenas de forma indireta, quando o código cuidava da cessão de crédito (art. 1.078) ${ }^{8}$, que mandava aplicar as disposições sobre a cessão de créditos à cessão de outros direitos (QUEIROGA, 2012, p. 36). A doutrina, por sua vez, aplicava à temática os princípios decorrentes da cessão de crédito e da venda de bem imóvel havido em condomínio.

\footnotetext{
${ }^{8} \mathrm{O}$ art. 1.078 do Código Civil de 1916 dispunha: "As disposições deste título aplicam-se à cessão de outros direitos para os quais não haja modo especial de transferência". (QUEIROGA, 2012, p. 36)

Revista Auditorium, Rio de Janeiro, v. 25, n. 52 p. 81-106, jul./out. 2021
} 
O Código Civil de 2002 inovou nesse ponto, regulando o assunto nos arts. 1.793 a 1.795. Subsidiariamente são ainda aplicáveis as normas pertinentes à cessão dos créditos obrigacionais (arts 286 a 298). E não poderia ser diferente, uma vez que o direito à sucessão aberta, como qualquer direito patrimonial disponível, passível de avaliação pecuniária, pode ser, em regra, transferido mediante cessão (MAIA JÚNIOR, 2018, p. 230-231).

Nessa linha, conforme estabelece o art. 1.793, o "direito à sucessão aberta, bem como o quinhão de que disponha o coerdeiro, pode ser objeto de cessão por escritura pública". A norma condiciona a cessão de direitos hereditários, também conhecida como cessão de herança, à abertura da sucessão, que somente ocorre com a morte do hereditando (QUEIROGA, 2012, p. 35).

De fato, com a abertura da sucessão é lícita a cessão de direitos hereditários, ainda que feita antes da abertura do inventário. Admite-se então a cessão de direitos hereditários desde o momento da abertura da sucessão até a ultimação da partilha (RIZZARDO, 2019, p. 90). Depois de julgada a partilha, estará extinta a indivisão, de modo que cada herdeiro será dono concretamente dos bens que couberem no seu quinhão, não fazendo sentido se falar mais em cessão de direitos hereditários, pois os direitos hereditários não são mais transmitidos, mas sim coisa determinada (OLIVEIRA; MELO, 2019, p. 150-151).

Por outro lado, antes da abertura da sucessão, para preservação da liberdade de testar ${ }^{9}$, bem como por fundamentos de natureza ética que remontam ao direito romano, não é possível a cessão de herança. É que isso configuraria pacto sucessório (pacta corvina) (CAPELO DE SOUSA, 2000, p. 47), ou seja, contrato cujo objeto é a herança de pessoa viva, o que é proibido pelo Código Civil (art. 426). A lei fulmina então com nulidade o negócio jurídico cujo objeto seja herança de pessoa viva (art. 166, II e VII), pois aos contratantes passaria a interessar a morte de alguém (votum

\footnotetext{
${ }^{9}$ A proibição dos pactos sucessórios também encontra fundamento na preservação da liberdade de testar. É que a admissão de um pacto sobre a sucessão futura, como ocorre nas contratações em geral, teria força obrigatória, o que entraria em choque com a possibilidade de revogação do testamento. Com isso, obrigando-se contratualmente, o autor da herança perderia sua liberdade de dispor mortis causa (PÉRÈS; VERNIÈRES, 2018, p. 322).

Revista Auditorium, Rio de Janeiro, v. 25, n. 52 p. 81-106, jul./out. 2021
} 
mortis) ${ }^{10}$.

Outrossim, é necessário fazer a distinção entre a cessão do direito à sucessão aberta e a cessão do quinhão de que disponha o coerdeiro. 0 art. 1.793 permite tanto a cessão do direito à sucessão aberta como a cessão do quinhão de que disponha o coerdeiro, exigindo-se, em qualquer caso, que o negócio jurídico seja realizado por escritura pública.

A cessão do direito à sucessão aberta ocorre quando o coerdeiro ainda não tiver declarado se aceita a herança, declaração esta que poderia ter se dado de forma expressa ou tácita. Logicamente, o coerdeiro apenas pode ceder direito que tenha aceitado, mas nesse caso ele não somente aceita a herança que lhe foi deferida como também a cede a outra pessoa. A cessão então se confunde com a aceitação, uma vez que se houve cessão por parte do herdeiro, foi porque aceitou a herança (QUEIROGA, 2012, p. 36).

Hipótese diversa se dá quando o herdeiro já aceitou a herança que Ihe foi oferecida e cede o quinhão de que dispõe, caso em que ocorre a cessão de direitos hereditários em momento cronologicamente posterior ao instante da aceitação (HIRONAKA, 2003, p. 73).

Outra distinção que deve ser feita é entre a cessão de direitos hereditários e a cessão de direitos de meação. A primeira cuida da herança, enquanto a segunda trata da meação, direito havido em função do regime patrimonial vigente no casamento, que também se extinguiu com a morte do autor da herança.

Em todo caso, deve ficar bem claro que a cessão de direito hereditários tem como objeto tão somente a transmissão de direitos de conteúdo econômico (direitos patrimoniais). Cede-se apenas a posição patrimonial do herdeiro (FRANK; HELMS, 2018, p. 301). Não é, e nem pode ser objeto de cessão a qualidade de herdeiro, que,

\footnotetext{
${ }^{10} \mathrm{O}$ art. 426 traz restrição jurídica tradicional, que está conforme a maior parte das legislações e tem suas raízes no direito romano. Trata-se de norma que tem cunho eminentemente moral, visto que "estipular contratualmente sobre a herança de pessoa viva é estipular pretendendo que o mais cedo possível ocorra a morte do que deixará a herança" (LOTUFO, 2016, p. 43). E nesse ponto é interessante notar que os pactos sucessórios (pacta successoria), em princípio, são inválidos nos países que adotam o sistema da civil law, uma vez que são considerados contrários à ordem pública (contra bonos mores). Entretanto, nos países de língua alemã, esses contratos são, excepcionalmente, válidos. Esse é o caso, por exemplo, da chamada donatio mortis causa, considerada válida (WAAL, 2006, p. 1087).

Revista Auditorium, Rio de Janeiro, v. 25, n. 52 p. 81-106, jul./out. 2021
} 
por se tratar de um direito fundamental previsto no art. 50, XXX da Constituição Federal, é intransmissível (FARIAS; ROSENVALD, 2020, p. 217).

\section{REQUISITOS PARA A CESSÃO DE DIREITOS HEREDITÁRIOS}

A cessão de direitos hereditários é um negócio jurídico que exige forma especial e solene, devendo ser celebrado por escritura pública (art. 1.793), a qual garante maior segurança e publicidade à transação ${ }^{11}$. As partes desse negócio jurídico são o cedente, isto é, o herdeiro, e o cessionário, ou seja, aquele que adquire a herança ou parte dela (LÔBO, 2021, p. 76).

Em face da exigência de forma especial, a cessão de direitos hereditários que não for feita por escritura pública é considerada nula de pleno direito, por não revestir a forma prescrita em lei (art. 166, IV) ${ }^{12}$. 0 art. 1.793 pôs então fim à polêmica que existia, estabelecendo que não é possível a cessão da herança com a utilização de instrumento particular ${ }^{13}$.

A escritura pública é indispensável mesmo que somente existam direitos pessoais ou coisas móveis na herança ${ }^{14}$, uma vez que o direito à sucessão aberta, até a partilha, é considerado como coisa imóvel para os efeitos legais (art. 80, II)

\footnotetext{
11 A formalidade exigida pelo direito brasileiro também é encontrada em outros ordenamentos jurídicos, como é o caso do alemão. De fato, o § 2033 do BGB requer que o negócio jurídico seja outorgado por instrumento notarial, dando maior proteção ao herdeiro diante de uma eventual conclusão contratual irrefletida (BROX; WALKER, 2016, p. 462). E o § 2371 do BGB ainda dispõe que "um contrato pelo qual o herdeiro vende a herança que the foi deferida deve ser outorgado por instrumento notarial" (FRANK; HELMS, 2018, p. 302).

12 Há na doutrina autores que consideram ser possível a cessão por termo nos autos (RIZZARDO, 2019, p. 93). Entretanto, a redação incisiva do art. 1.793 do Código Civil, que impõe a escritura pública, parece não dar margem a tal tipo de interpretação. A despeito disso, existem julgados que flexibilizam a legislação, permitindo, particularmente no caso de móveis, a cessão por termo nos autos.

${ }^{13}$ Acerca da exigência de escritura pública como condição de validade da cessão de direitos hereditários já se manifestou o Superior Tribunal de Justiça: "A cessão de direitos hereditários deve ser formalizada por escritura pública, consoante determina o art. 1.793 do Código Civil de 2002" (Superior Tribunal de Justiça. Ag no REsp 1.416.041/RS. Relator: Min. Sidnei Beneti. Brasília, 22 de maio de 2014).

${ }^{14}$ O Código Civil português, em seu art. 2126, cuidou da matéria de forma diversa e com maior precisão, dispondo: "1. A alienação de herança ou quinhão hereditário será feita por escritura pública, se existirem bens cuja alienação deva ser feita por essa forma. 2. Fora do caso previsto no número anterior, a alienação deve constar de documento particular". Em face da melhor redação, que inclusive elimina maiores formalidades no que toca aos bens móveis, acredita-se que seria o caso de uma revisão da legislação brasileira, a qual deveria se alinhar ao disposto no Código Civil português.

Revista Auditorium, Rio de Janeiro, v. 25, n. 52 p. 81-106, jul./out. 2021
} 
(AZEVEDO, 2019, p. 27). O registro público, por seu turno, não se faz necessário, uma vez que o cessionário, ao assumir a posição de herdeiro, é alcançado pela transmissão da posse e da propriedade desde a abertura da sucessão (princípio da saisine).

Aplica-se então à universalidade hereditária, como consequência, o regime jurídico dos bens imóveis (PENTEADO, 2014, p. 40), ressalvando-se, entretanto, o disposto no art. 108, que autoriza a celebração de negócios jurídicos imobiliários por instrumento particular, quando o seu objeto não exceder trinta salários-mínimos, norma que não se aplica à cessão de direitos hereditários, haja vista a aplicação do critério da especialidade (lex speciallis derrogat lex generalis) (FARIAS; ROSENVALD, 2020, p. 229).

Nesse contexto, a imobilização da massa hereditária tem efeitos no que toca à cessão de direitos hereditários, mas vai além, pois também tem reflexos em demandas judiciais (MONTEIRO, 2016, p. 48). De fato, se o herdeiro cedente for casado, é necessária a autorização do outro cônjuge (outorga conjugal) ${ }^{15}$ para a cessão, salvo se o regime de bens for o da separação absoluta (art. 1.647, I) (PEREIRA, 2017, p. 65) ou se casado no regime de participação final nos aquestos, houver pacto antenupcial prevendo a desnecessidade da outorga conjugal para a disposição de bens imóveis (art. 1.656). Trata-se de hipótese de legitimação, de maneira que a falta de autorização, quando o cônjuge devia dá-la, tornará anulável o ato praticado (art. 1.649). Caso o cônjuge imotivadamente recuse a concessão da autorização para a realização da cessão de herança, é cabível o suprimento judicial por meio de um procedimento de jurisdição voluntária.

A cessão de direitos hereditários é um negócio jurídico bilateral inter vivos, exigindo-se a manifestação de vontade isenta de vícios e a perfeita identificação das partes que o celebraram (MAIA JÚNIOR, 2018, p. 231). Somente pode ser realizado pelo herdeiro legítimo ou testamentário depois da abertura da sucessão.

Admite-se a cessão de toda a herança, hipótese em que o cedente é herdeiro único, ou de parte da herança. Pode ainda ter por objeto a totalidade do

${ }^{15}$ Fala-se em outorga uxória, quando dependente da esposa, ou outorga marital, se provém do marido.

Revista Auditorium, Rio de Janeiro, v. 25, n. 52 p. 81-106, jul./out. 2021 
quinhão hereditário (cessão total) ou apenas parte dele (cessão parcial), sendo necessário para a validade do negócio que tais informações sejam claramente consignadas na escritura. Aliás, se a cessão abranger a totalidade da herança, o herdeiro afasta-se do inventário (NADER, 2016, p. 45).

O herdeiro pode efetuar a cessão de forma gratuita ou onerosa. A cessão importa em alienação, equiparando-se a cessão gratuita à doação e a cessão onerosa à compra e venda, de sorte que são aplicáveis, por analogia, as normas que regem referidos contratos (FARIAS; ROSENVALD, 2020, p. 217). Nessa linha, a cessão onerosa gera a obrigação de pagar o imposto sobre transmissão de bens inter vivos (ITBI), de competência municipal (art. 156, II da CF), enquanto a cessão gratuita, por apresentar natureza de liberalidade, remete ao pagamento do imposto sobre a doação (ITCMD), previsto no art. 155, I da CF. Por isso, é fundamental que se deixe consignado na escritura se se trata de cessão gratuita ou onerosa.

Por derradeiro, não se admite a cessão de direitos hereditários na hipótese de imposição de cláusula de inalienabilidade pelo testador ou de instituição de fideicomisso relativamente aos direitos hereditários em questão. A cláusula de inalienabilidade, que deve ser expressa na declaração de vontade, impede justamente o herdeiro de dispor, não havendo que se falar em cessão. No fideicomisso, por sua vez, a natureza da propriedade é resolúvel, de modo que não existe a possibilidade de sua transmissão em caráter definitivo a terceiros (MAIA JÚNIOR, 2018, p. 233).

\section{CESSÃO DE BENS INDIVIDUADOS}

O cedente não transfere um bem individuado integrante do espólio, isto é, não pode ceder um bem como unidade autônoma da herança. $O$ que o cedente transfere é o direito sobre sua quota-parte ou parcela de quota-parte da herança, uma vez que nenhum bem deixado pelo testador pertence a determinado herdeiro (LÔBO, 2021, p. 77). Isso decorre da indivisibilidade da herança como um todo e da incerteza no que toca aos bens que caberão a cada coerdeiro quando ultimada a partilha. É então ineficaz a cessão, pelo coerdeiro, de seu direito hereditário sobre Revista Auditorium, Rio de Janeiro, v. 25, n. 52 p. 81-106, jul./out. 2021 
qualquer bem ou direito da herança considerado singularmente (art. 1.793, § $2^{\circ}$ ).

Admite-se, entretanto, que o cedente especifique um bem como integrante da quota-parte que está cedendo, mas tal determinação não tem caráter obrigatório para os demais coerdeiros. Caso estes concordem com a cláusula inserida no instrumento de cessão, podem aquiescer que o bem especificado componha a cessão. Mister se faz repetir, contudo, que isso não pode ser imposto aos coerdeiros, que podem fazê-lo simplesmente por cortesia. O adquirente corre então o risco de comprar determinado bem que não venha a ser atribuído ao herdeiro. Em todo caso, com a entrega do objeto da cessão, o negócio jurídico produzirá o efeito jurídico desejado (NADER, 2016, p. 48).

O herdeiro pode, excepcionalmente, pretender dispor de bem componente do acervo hereditário, pendente de indivisibilidade. Para tanto, é necessário o acordo dos interessados e a alienação do bem ainda depende de prévia autorização do juiz competente, que só o fará provocado pela parte interessada em ceder o bem. A necessidade de prévia autorização judicial objetiva garantir o controle dos atos de disposição de cada herdeiro, preservando os direitos dos demais herdeiros, que devem ser intimados. Sem a observância dessas formalidades a disposição é ineficaz (art. 1.793, § $3^{\circ}$ ). Nada impede, entretanto, que a autorização judicial seja concedida em momento posterior à celebração da cessão, caso em que terá natureza jurídica de ratificação, retroagindo à data da cessão (art. 873). Ademais, vale ainda observar que se a intenção de ceder partiu de um dos herdeiros, caso realmente se materialize a cessão de um bem específico, ao mencionado herdeiro deve ser atribuída a diminuição de sua quota-parte (HIRONAKA, 2003, p. 75).

E a situação anterior não deve ser confundida com a venda de determinado bem feita pelo próprio espólio, por meio do inventariante, mediante autorização judicial (art. 619, I do CPC) (OLIVEIRA; MELO, 2019, p. 155). A venda de bem que integra o espólio pode ser autorizada com fundamento em hipóteses bastante diversas: para o pagamento de dívidas da herança, de custas, de imposto de transmissão mortis causa ou outros encargos, para atender a necessidade urgente dos herdeiros, por estar algum imóvel se deteriorando, sendo conveniente a sua alienação etc. (RODRIGUES, 2003, p. 28). Ademais, se a venda foi feita em nome do Revista Auditorium, Rio de Janeiro, v. 25, n. 52 p. 81-106, jul./out. 2021 
espólio, admite-se desde já, caso se trate de imóvel, a realização do registro, mantendo-se o princípio da continuidade (RIZZARDO, 2019, p. 99).

\section{A RESPONSABILIDADE DO CEDENTE E DO CESSIONÁRIO}

A cessão de direitos hereditários é, ressalvada disposição em sentido contrário decorrente da vontade expressa das partes, um negócio jurídico aleatório, haja vista a indeterminação de seu objeto, que fica subordinado à partilha que dividirá, após o pagamento dos credores, os bens remanescentes. É que o cessionário não tem certeza quanto ao eventual recebimento de valor superior ou inferior àquele pago pela cessão do direito hereditário (FARIAS; ROSENVALD, 2020, p. 231). Por isso, aquilo que o cessionário vai receber na partilha pode ficar aquém ou além de sua expectativa ${ }^{16}$.

Com a realização da cessão, o cessionário passa a ocupar a posição jurídica do cedente, isto é, sub-roga-se, total ou parcialmente, nos direitos e obrigações, como se fosse o próprio herdeiro. Desse modo, responde o cessionário pelas dívidas do espólio, até o valor do quinhão respectivo do cedente, podendo ocorrer que nada receba, caso o quinhão cedido venha a ser comprometido para o pagamento dos débitos. Não responde, entretanto, pelas dívidas do cedente, mas tão somente pelas dívidas do autor da herança (HIRONAKA, 2003, p. 72). Por isso, afirma-se que o cessionário, na qualidade de adquirente da quota, apenas responde pelas dívidas intra vires hereditatis (RIZZARDO, 2019, p. 97).

Os atos que o herdeiro poderia praticar para defender, conservar, modificar ou extinguir seu direito poderão ser praticados pelo cessionário, que receberá na partilha o que caberia ao cedente ${ }^{17}$. 0 cessionário poderá, inclusive, requerer a abertura de inventário ou, já estando em curso o procedimento, praticar os atos

\footnotetext{
${ }^{16}$ Acerca do caráter aleatório da cessão, Ney de Mello Almada é categórico: "não há como negar o caráter aleatório, pois, no momento cronológico do contrato, não têm as partes noção precisa da extensão da obrigação de entrega da coisa hereditária, não se descartando venha o cessionário a auferir menos ou acima do esperado, em função de possível variação quantitativa da quota cedida no interstício entre a data da cessão e a partilha" (ALMADA, 2006, p. 105).

${ }^{17}$ Conforme esclarece Ascensão, o adquirente tem, em princípio, "todos os poderes de defesa da sua posição que caberiam ao alienante" (ASCENSÃO, 2000, p. 489).

Revista Auditorium, Rio de Janeiro, v. 25, n. 52 p. 81-106, jul./out. 2021
} 
processuais subsequentes. Também poderá ajuizar ações reivindicatórias, de nulidade de testamento, de petição de herança, impugnação de cálculos etc.

A herança é recebida pelo beneficiário da cessão no estado em que se encontra. O cessionário se coloca então no lugar do herdeiro (FRANK; HELMS, 2018, p. 302). Nada impede que no decorrer do inventário a herança seja consumida pelas dívidas do falecido. Em tal situação, o cedente não poderá ser responsabilizado, uma vez que não é garante do valor da herança ${ }^{18}$. Contudo, poderá existir responsabilidade quando houver má-fé por parte do herdeiro ou quando no negócio jurídico de cessão constar previsão no sentido de que o herdeiro cede direitos hereditários de valor determinado (HIRONAKA, 2003, p. 76).

Assim sendo, como regra, caso o cessionário não venha a receber o valor esperado, ou receba menos do que investiu, não poderá exigir ressarcimento do cedente em relação ao prejuízo sofrido. É que o cedente garante tão somente a sua qualidade de titular do patrimônio transferido, a sua condição de herdeiro, tanto que se o cedente não for reconhecido como herdeiro, deverá restituir os valores recebidos, com o acréscimo de eventuais perdas e danos (NADER, 2016, p. 43).

Ademais, considerando que o cessionário recebe a herança no estado em que se acha, há situações jurídicas que, salvo deliberação expressa em sentido contrário, não estão compreendidas na cessão, que não beneficiam o cessionário. Nessa senda, o art. 1.793, § 10 limita o direito do cessionário, excluindo da cessão de direitos hereditários os adquiridos a posteriori pelo cedente.

De fato, após o aperfeiçoamento da cessão, os direitos conferidos ao herdeiro em consequência de substituição (art. 1.947) ${ }^{19}$ ou de direito de acrescer (art. 1.941$)^{20}$, presumem-se não abrangidos pela cessão feita anteriormente (art. $\left.1.793, \S 1^{\circ}\right)$, uma vez que a cessão não alcança o que, posteriormente, tenha sido

\footnotetext{
${ }^{18}$ A solução dada pelo direito alemão não é diferente, uma vez que o vendedor da herança não responde pelo seu valor e nem por determinado bem a integrar, salvo se houver disposição contratual especial em sentido diverso (LEIPOLD, 2012, p. 360).

${ }^{19}$ A substituição está regulada nos arts. 1.947 a 1.960, decorrendo de uma "disposição testamentária em que o testador indica uma terceira pessoa para receber uma gratificação testamentária, na falta de um herdeiro, ou legatário, indicado em primeiro lugar, ou após este" (RODRIGUES, 2003, p. 198).

${ }^{20} \mathrm{O}$ direito de acrescer se materializará quando, sendo vários os herdeiros testamentários ou os legatários nomeados pelo testador, um deles não chega a adquirir sua parte por premoriência, incapacidade ou renúncia, o que acarretará o acréscimo do seu quinhão no dos outros (LEITE, 2003, p. 81).

Revista Auditorium, Rio de Janeiro, v. 25, n. 52 p. 81-106, jul./out. 2021
} 
acrescido à herança ${ }^{21}$. Por conseguinte, como esses novos direitos sucessórios não se transmitem ao cessionário, mas se consolidam na pessoa do herdeiro cedente, este volta a ser chamado a suceder no que diz respeito aos bens supervenientes (LÔBO, 2021, p. 77).

\section{O DIREITO DE PREFERÊNCIA DOS COERDEIROS}

O direito de preferência ou prelação determina que se um coerdeiro pretende vender o seu quinhão hereditário, deve oferecê-lo primeiramente aos demais coerdeiros, sob pena de ineficácia. Trata-se de importante inovação da legislação de 2002, uma vez que o Código Civil de 1916 não continha previsão expressa nesse sentido, o que gerava discussões acerca da necessidade, ou não, de se garantir o direito de preferência aos demais coerdeiros (FARIAS; ROSENVALD, 2020, p. 220).

Nesse contexto, a cessão da quota hereditária, pelo coerdeiro, a pessoa estranha à sucessão ficará inviabilizada, será ineficaz, se outro coerdeiro a quiser para si. É que se aplicam aos coerdeiros as normas relativas ao condomínio, dentre as quais o direito de preferência ${ }^{22}$. Assim sendo, partindo dos princípios que regem o condomínio, o coerdeiro não poderá ceder a sua quota hereditária a pessoa estranha à sucessão, se outro herdeiro a quiser, tanto por tanto. Isso significa que se for oferecido o mesmo valor e idêntica condição de pagamento, outro coerdeiro tem preferência na aquisição da quota hereditária que está sendo cedida a terceiro (art. 1.794).

A expressão "tanto por tanto", constante do art. 1.794, tem então o significado de "nas mesmas condições", submetendo-se aos mesmos ônus, considerando o mesmo preço oferecido pelo terceiro estranho à sucessão que se beneficiária com o negócio jurídico oneroso de cessão (HIRONAKA, 2003, p. 78). Por

\footnotetext{
${ }^{21}$ No mesmo sentido dispõe o art. 2125, 2 do Código Civil português: "A parte hereditária devolvida ao alienante, depois da alienação, em consequência de fideicomisso ou do direito de acrescer, presume-se excluída da disposição".

${ }_{22}$ O § 2034 do BGB apresenta disposição semelhante, estabelecendo que se um coerdeiro vender sua parte a um terceiro, os outros coerdeiros terão direito de preferência, que deve ser exercido no prazo de dois meses. A legislação alemã ainda determina que o direito de preferência é transferível em caso de morte (FRANK; HELMS, 2018, p. 300).

Revista Auditorium, Rio de Janeiro, v. 25, n. 52 p. 81-106, jul./out. 2021
} 
isso, não exerce o direito de preferência o coerdeiro que faz contraproposta diferente da que ofereceu o estranho (LÔBO, 2021, p. 77).

A lógica do código é evitar o ingresso de estranhos na comunhão hereditária. Como se sabe, a comunhão é uma fonte de discórdias e desavenças, situação que pode piorar com 0 ingresso de um estranho no condomínio ${ }^{23}$. Diante disso, o art. 1.794 estabeleceu que existe o direito de preferência entre os coerdeiros, solução que merece elogios, uma vez que não seria razoável negar aos herdeiros a prerrogativa de adquirir a herança com preferência em relação a estranhos (VENOSA, 2019, p. 1552).

O direito de preferência só pode ser exercido em relação a terceiros e diante de cessões onerosas, o que se depreende da referida expressão "tanto por tanto". Isso porque a cessão onerosa não representa liberalidade de cunho altruístico, mas verdadeiro negócio jurídico movido pela expectativa de vantagem econômica. Assim sendo, nenhum prejuízo acarretará para o cedente ver o cessionário substituído por um dos coerdeiros (HIRONAKA, 2003, p. 79).

Não há que se falar em direito de preferência do coerdeiro se a transferência da quota hereditária é feita de forma gratuita, a qual possui a natureza de doação. Na cessão a título gratuito fica a critério do herdeiro a escolha daquele que deseja beneficiar (AMORIM; OLIVEIRA, 2020, p. 67). Também não existe direito de preferência se o coerdeiro cede o seu quinhão a outro coerdeiro, que, logicamente, não é pessoa estranha à sucessão. É que nesse caso não existe o risco de estranhos ingressarem na comunhão hereditária, podendo então um herdeiro ceder direitos a outro sem a necessidade de prévia comunicação dos demais coerdeiros (NADER, 2016, p. 48).

Outrossim, não existe direito de preferência na hipótese de cessão de legado, visto que se trata de sucessão a título singular, que não vai levar ao estabelecimento de um condomínio. Contudo, excepcionalmente isso pode ocorrer, no caso de legado em favor de duas ou mais pessoas, em condomínio pro indiviso

\footnotetext{
${ }^{23}$ Sobre esse tema leciona Washington de Barros Monteiro: "é natural que, em se tratando de patrimônio de cunho preponderantemente familiar, desejem os herdeiros que os bens que o compõem permaneçam entre os seus integrantes, afastando a comunhão com terceiros" (MONTEIRO, 2016, p. 36).

Revista Auditorium, Rio de Janeiro, v. 25, n. 52 p. 81-106, jul./out. 2021
} 
(FARIAS; ROSENVALD, 2020, p. 227).

O coerdeiro, a quem não se der conhecimento da cessão, por inércia ou má-fé do cedente, poderá, depositado o preço, haver para si a quota cedida onerosamente a estranho, se o requerer até cento e oitenta dias após a transmissão, isto é, o prazo decadencial, cujo curso não se interrompe, é contado da celebração do negócio jurídico (PEREIRA, 2017, p. 66) ${ }^{24}$. Nesse caso, o negócio jurídico celebrado é válido e eficaz entre as partes, mas é ineficaz em relação aos coerdeiros prejudicados, que deveriam ter sido cientificados por escrito da cessão onerosa da quota hereditária (FARIAS; ROSENVALD, 2020, p. 222).

$\mathrm{O}$ art. 1.795, caput, acaba repetindo o que já havia sido determinado pelo art. 504, caput, ao regular a venda de coisa indivisível em condomínio. Em todo caso, resolve antiga divergência jurisprudencial acerca da necessidade de anuência dos coerdeiros para a cessão de quota hereditária.

Pode ainda ocorrer de vários coerdeiros resolverem exercer o direito de preferência sobre o que foi cedido a estranho, depositando judicialmente a totalidade do valor da cessão. Nessa situação, o código determina que se distribuirá entre eles o quinhão cedido, na proporção das respectivas quotas hereditárias (art. 1.795, parágrafo único) (AZEVEDO, 2019, p. 28), ou seja,

se as quotas dos coerdeiros forem iguais, o valor da parte ideal cedida, fixada na escritura de cessão ao terceiro, será dividido entre eles para compor o depósito; se forem desiguais, de acordo com a proporção de cada uma (LÔBO, 2021, p. 78).

Garante-se, assim, a participação de todos os herdeiros interessados na cessão que se pretende realizar (MAIA JÚNIOR, 2018, p. 237), não se estabelecendo critérios de desempate entre os coerdeiros que queiram exercer o direito de

${ }^{24} \mathrm{Em}$ sentido contrário, há na doutrina entendimento que considera que a fluência do prazo decadencial de cento e oitenta dias para a propositura da demanda deve ocorrer a partir do conhecimento da alienação ao terceiro e não da data da celebração do contrato. Argumenta-se que "o prazo não pode ter iniciada a sua fluência enquanto não for possível ao titular a propositura da ação" (FARIAS; ROSENVALD, 2020, p. 224). Na mesma linha, obtempera José Luiz Gavião de Almeida que não "se poderia considerar termo inicial do prazo para que fizessem valer seus direitos uma data da qual não tiveram ciência. Os prazos decadenciais e o disposto no artigo 1.795 é um deles, faz perecer o direito de agir pela inércia de seu titular. Mas não se pode entender desidioso aquele que não teve oportunidade de defender seus interesses" (ALMEIDA, 2003, p. 91). Vê-se então que a regra do art. 1.795 , ao prever o prazo de cento e oitenta dias, é quase idêntica àquela para a venda de bem indivisível em que houve preterição de condômino, havendo diferença no que toca à não menção do início de sua contagem, o que gera divergência na doutrina (QUEIROGA, 2012, p. 39).

Revista Auditorium, Rio de Janeiro, v. 25, n. 52 p. 81-106, jul./out. 2021 
preferência, de maneira que todos os interessados ficam com o quinhão, na proporção de sua participação na herança (QUEIROGA, 2012, p. 39). E tal solução difere da que ocorre no concurso entre vários comunheiros que exercem o direito de preferência no condomínio tradicional, conforme estabelece o art. 504 do Código Civil.

Por conseguinte, admite-se a cessão a estranho apenas quando:

a) for comunicada previamente aos demais coerdeiros; b) for dada preferência aos demais coerdeiros para aquisição da parte ideal, pelo mesmo preço que o estranho ofereceu, 'tanto por tanto'; c) os demais coerdeiros não exercitarem a preferência dentro do prazo concedido (LÔBO, 2021, p. 77).

\section{A COMUNICAÇÃO DOS COERDEIROS}

A cessão de direitos hereditários a terceiros exige comunicação adequada dos coerdeiros, também conhecida como denuntiatio. De fato, é necessário que se dê conhecimento da cessão aos coerdeiros, para que eventualmente possam exercer seu direito de preferência.

O ônus de notificar os demais herdeiros, bem como de fazer a prova da sua realização, é do herdeiro cedente. Tal prova é feita por declaração dos condôminos no sentido de não terem interesse na aquisição tanto por tanto, uma vez conhecidas as condições econômicas e jurídicas do negócio (HIRONAKA, 2003, p. 79).

Para tanto, admite-se qualquer meio de ciência inequívoca dos coerdeiros, inclusive a interpelação por meios eletrônicos, desde que seja possível demonstrar a autenticidade da comunicação virtual, o que está em consonância com a liberdade de forma das declarações de vontade, quando não há previsão legal em sentido contrário (art. 107).

A comunicação para o exercício do direito de preferência, além de cientificar acerca da intenção de ceder onerosamente direitos hereditários, também devem informar as condições do negócio a ser realizado, isto é, o preço e as condições de pagamento, pois somente assim os interessados podem avaliar se têm interesse na aquisição da fração ideal da herança ${ }^{25}$.

\footnotetext{
${ }^{25}$ Nesse sentido já se manifestou o Superior Tribunal de Justiça: "a prévia notificação dos coerdeiros, para fins do exercício de seu direito de preferência, deve ser capaz de assegurar-Ihes plena ciência Revista Auditorium, Rio de Janeiro, v. 25, n. 52 p. 81-106, jul./out. 2021
} 
Na hipótese de exercício do direito de preferência, é imprescindível o depósito do valor correspondente ao preço indicado na notificação, bem como demais despesas apresentadas. Aliás, acerca desse depósito, Otávio Luiz Rodrigues Júnior assevera que sua efetivação é conditio sine qua non para o exercício da prelação. Assim sendo, "os pretendentes à preempção devem fazê-lo com pontual e perfeito cumprimento da obrigação de depositar as quantias desembolsadas pelo adquirente, sem o que a preferência não pode ser admitida" (RODRIGUES JUNIOR, 2003, p. 296).

Outrossim, é necessário que o coerdeiro, que adquiriu a cota hereditária pelo exercício do direito de prelação, comunique a juízo do inventário para que sejam tomadas as providências processuais cabíveis.

\section{A AÇÃO DE PREFERÊNCIA}

A ação que objetiva declarar que a cessão da herança não produziu efeitos em relação ao coerdeiro é chamada de ação de preferência. Submete-se ao procedimento comum, e seu objetivo é a obtenção da aquisição forçada da cota-parte hereditária alienada onerosamente (adjudicação compulsória), independentemente da vontade do alienante e do terceiro adquirente (FARIAS; ROSENVALD, 2020, p. 222).

Ao propor a ação, a parte autora deve requerer o depósito do valor do negócio tanto por tanto. No polo passivo é necessária a presença tanto do alienante como do adquirente, uma vez que a decisão vai afetá-los. Se não for feita a citação dos litisconsortes necessários, a ação de preferência será nula, conforme dispõe o art. 115 do Código de Processo Civil (FARIAS; ROSENVALD, 2020, p. 223).

O magistrado, ao julgar a demanda, reconhece a preterição indevida da preferência do autor, deferindo-Ihe a contratação forçada e a consequente aquisição da cota-parte hereditária. O valor depositado, considerando a formação do

não apenas do interesse do herdeiro cedente na alienação futura de sua cota hereditária, mas também do preço e das condições de pagamento oferecidas ao pretenso terceiro cessionário" (Superior Tribunal de Justiça. REsp 1620705/RS. Relator: Min. Ricardo Villas Bôas Cueva. Brasília, 21 de novembro de 2017).

Revista Auditorium, Rio de Janeiro, v. 25, n. 52 p. 81-106, jul./out. 2021 
litisconsórcio passivo necessário na demanda, reverterá em favor do terceiro adquirente. É possível, contudo, o ajuizamento de nova ação indenizatória por parte desse terceiro, cobrando-lhe eventuais perdas e danos que considere ainda existentes em virtude da utilização da regra do art. 1.795.

\section{O DIREITO DE ARREPENDIMENTO}

A legislação não prevê a possibilidade de desistência da cessão onerosa pelo alienante após o exercício do direito de preferência pelo coerdeiro. Em face da ausência de previsão, indaga-se então se é possível o direito de arrependimento por parte do alienante.

Como o sistema jurídico não proíbe, parece mais razoável a interpretação no sentido de que o alienante pode desistir da celebração do negócio jurídico de cessão, ainda que isso ocorra após a notificação dos coerdeiros e eventual manifestação pelo exercício do direito de preferência. Contudo, é de se notar que se o exercício do arrependimento causar prejuízos ao preferente, será necessário o seu ressarcimento, incluindo aí eventuais lucros cessantes ${ }^{26}$.

\section{CONSIDERAÇÕES FINAIS}

Incontestável foi o benefício obtido com a previsão expressa acerca da cessão de herança no Código Civil atual. As celeumas, porventura criadas a respeito, foram assim sucumbidas com a pá de cal que o legislador lançou sobre as mesmas. De fato, a regulação apresentada pela codificação proporciona maior segurança jurídica, valor que sem dúvida é buscado pelo operador do direito. Além disso, as regras criadas garantem mais clareza.

No que tange à forma, muito embora se adote há muito o princípio do consensualismo, sempre poderia surgir questionamento pelo que dispõe o art. 108

\footnotetext{
${ }^{26} \mathrm{O}$ Código Civil português, diferentemente do direito pátrio, regulou a matéria em seu art. 1.410, 2, dispondo: "O direito de preferência e a respectiva ação não são prejudicados pela modificação ou distrate da alienação, ainda que estes efeitos resultem de confissão ou transação judicial".

Revista Auditorium, Rio de Janeiro, v. 25, n. 52 p. 81-106, jul./out. 2021
} 
do Código Civil, não obstante ter o legislador colocado o direito à sucessão aberta como bem imóvel para efeitos legais. A forma escrita, no caso, é ad substantia, mas também facilita a prova de maneira inconteste. Ainda, diferentemente do que ocorre quando o negócio jurídico é verbal, a imposição do requisito formal também constitui um empecilho em relação a medidas precipitadas, que muitas vezes ocorrem em convenções verbais.

Entretanto, vale notar, não inovou em muito o legislador pátrio, tendo sedimentado princípios fundamentais que a doutrina e jurisprudência já haviam abraçado no curso da vigência do diploma civil passado. Houve dissipação de dúvidas em relação à forma, às pessoas entre as quais a cessão é celebrada e aos direitos a eles pertinentes, como o da faculdade de adjudicação compulsória, o que, por si só já representa grande evolução, haja vista a relevância prática da matéria. Contudo, isso não significa que cessaram todas as possíveis indagações passíveis de se apresentarem, sendo certo que muitas questões ainda poderão suscitar novos debates.

\section{REFERÊNCIAS}

ALMADA, Ney de Mello. Sucessões. São Paulo: Malheiros, 2006.

ALMEIDA, José Luiz Gavião de; AZEVEDO, Álvaro Villaça (coord.). Código civil comentado: direito das sucessões, sucessão em geral, sucessão legítima: artigos 1.784 a 1.856. São Paulo: Atlas, 2003. v. XVIII.

AMORIM, Sebastião; OLIVEIRA, Euclides de. Inventário e partilha: teoria e prática. 26. ed. São Paulo: Saraiva, 2020.

APATHY, Peter; KLINGENBERG, Georg; PENNITZ, Martin. Einführung in das römische Recht. 6. ed. Wien: Böhlau, 2016.

ASCENSÃO, José de Oliveira. Direito Civil: Sucessões. 5. ed. Coimbra: Coimbra, 2000.

AZEVEDO, Álvaro Villaça. Curso de direito civil: direito das sucessões. São Paulo: Saraiva, 2019. v. 7. 
BRASIL. Lei $\mathbf{n}^{\mathbf{0}} \mathbf{1 0 . 4 0 6}$, de 10 de janeiro de 2002. Institui o Código Civil. Brasília, DF: Presidência da República, [2002]. Disponível em:

http://www.planalto.gov.br/ccivil_03/leis/2002/L10406compilada.htm. Acesso em: 27 out. 2021.

BRASIL. Lei n 13.105, de 16 de março de 2015. Código de Processo Civil. Brasília, DF: Presidência da República, [2015]. Disponível em: http://www.planalto.gov.br/ccivil_03/_ato2015-2018/2015/lei/l13105.htm. Acesso em: 27 out. 2021.

BRASIL. Superior Tribunal de Justiça. AgRg no Recurso Especial No

1.416.041/RS. Agravo regimental no recurso especial. Execução de título extrajudicial. Ofensa ao art. 535 do CPC. Coisa julgada. Súmula 211/STJ. Nulidade da cessão de direitos hereditários. Precedentes. Súmulas 7/STJ e 283/STF. Improvimento. Brasília, DF: Supremo Tribunal de Justiça, [2014]. Disponível em: https://stj.jusbrasil.com.br/jurisprudencia/25122445/agravo-regimental-no-recurso-e special-agrg-no-resp-1416041-rs-2013-0367980-2-stj/inteiro-teor-25122446. Acesso em: 27 out. 2021.

BRASIL. Superior Tribunal de Justiça. Recurso especial No 1.620.705/RS (2013/0396090-1). Recurso especial. Direito Civil e Processual Civil. Sucessões. Violação do art. 535 do COC/1973. Não ocorrência. Inventário. Agravo de Instrumento. Art. 522 do CPC/1973. Cessão onerosa de quota hereditária à terceiro. Direito de preferência dos coerdeiros. Arts. 1.794 e 1.795 do Código Civil. Aquisição tanto por tanto. Notificação prévia. Necessidade. Indicação de preço e condições de pagamento. Imprescindibilidade. Brasília, DF: Superior Tribunal de Justiça, [2017]. Disponível em:

https://stj.jusbrasil.com.br/jurisprudencia/526808895/recurso-especial-resp-1620705 -rs-2013-0396090-1/inteiro-teor-526808905. Acesso em: 27 out. 2021.

BROX, Hans; WALKER, Wolf-Dietrich. Erbrecht. 27. ed. München: Franz Vahlen, 2016.

CAPELO DE SOUSA, Rabindranath. Lições de direito das sucessões. 4. ed. Coimbra: Coimbra, 2000. v. I.

DINIZ, Maria Helena. Curso de direito civil brasileiro. 35. ed. São Paulo: Saraiva, 2021. v. 6.

FARIAS, Cristiano Chaves de; ROSENVALD, Nelson. Curso de direito civil: sucessões. 6. ed. Salvador: JusPodivm, 2020. v. 7.

FRANK, Rainer; HELMS, Tobias. Erbrecht. 7. ed. München: C.H. Beck, 2018.

GOMES, Orlando. Sucessões. 16. ed. Rio de Janeiro: Forense, 2015. 
GONÇALVES, Carlos Roberto. Direito civil brasileiro: direito das sucessões. 13. ed. São Paulo: Saraiva, 2019. v. 7.

GOZZO, Débora; VENOSA, Silvio de Salvo; ALVIM, Arruda (coord.); ALVIM, Thereza (coord.). Comentários ao Código civil brasileiro: do direito das sucessões. Rio de Janeiro: Forense, 2004, v. XVI.

HIRONAKA, Giselda Maria Fernandes Novaes; AZEVEDO, Antônio Junqueira de (coord.). Comentários ao Código Civil: parte especial: do direito das sucessões: arts 1.784 a 1.856. São Paulo: Saraiva, 2003. v. 20.

KASER, Max; KNÜTEL, Rolf; LOHSSE, Sebastian. Römisches Privatrecht. 21. ed. München: C.H. Beck, 2017.

LEIPOLD, Dieter. Erbrecht. 19. ed. Tübingen: Mohr Siebeck, 2012.

LEITE, Eduardo de Oliveira. Comentários ao Novo Código Civil: do direito das sucessões (arts. 1.784 a 2.027). Rio de Janeiro: Forense, 2003. v. XXI.

LÔBO, Paulo. Direito civil: sucessões. 7. ed. São Paulo: Saraiva, 2021. v. 6.

LOTUFO, Renan. Código civil comentado: contratos em geral até doação (arts. 421 a 564). São Paulo: Saraiva, 2016. v. 3.

MAIA JÚNIOR, Mairan Gonçalves. Sucessão legítima: as regras da sucessão legítima, as estruturas familiares contemporâneas e a vontade. São Paulo: Revista dos Tribunais, 2018.

MONTEIRO, Washington de Barros. Curso de direito civil: direito das sucessões. 39. ed. São Paulo: Saraiva, 2016. v. 6.

NADER, Paulo. Curso de direito civil. 7. ed. Rio de Janeiro: Forense, 2016. v. 6.

OLIVEIRA, J. M. Leoni Lopes de; MELO, Marco Aurélio Bezerra de. Direito civil: sucessões. 2. ed. Rio de Janeiro: Forense, 2019.

PENTEADO, Luciano de Camargo. Manual de direito civil: sucessões. São Paulo: Revista dos Tribunais, 2014.

PEREIRA, Caio Mário da Silva. Instituições de Direito civil. 24. ed. Rio de Janeiro: Forense, 2017. v. VI.

PÉRÈS, Cécile; VERNIÈRES, Christophe. Droit des successions. Paris: PUF, 2018. POLETTO, Carlos Eduardo Minozzo. Indignidade sucessória e deserdação. São Paulo: Saraiva, 2013. 
PORTUGAL. Decreto-Lei no 47344, de 25 de novembro de 1966. Aprova o Código Civil e regula a sua aplicação - Revoga, a partir da data da entrada em vigor do novo Código Civil, toda a legislação civil relativa às matérias que o mesmo abrange. Lisboa: Ministério da Justiça, [1966]. Disponível em: https://dre.pt/web/guest/legislacao-consolidada//lc/106487514/202110272121/73407012/diplomaExpandido. Acesso em: 27 out. 2021.

QUEIROGA, Antônio Elias de. Curso de direito civil: direito das sucessões. 2. ed. Rio de Janeiro: Renovar, 2012.

RIZZARDO, Arnaldo. Direito das Sucessões. 11. ed. Rio de Janeiro: Forense, 2019. RODRIGUES JUNIOR, Otavio Luiz. Código civil comentado: Compra e venda. Troca. Contrato Estimatório: artigos 481 a 537. AZEVEDO, Álvaro Villaça (coord.). São Paulo: Atlas, 2003. v. VI. t. I.

RODRIGUES, Silvio. Direito civil: Direito das Sucessões. 26. ed. São Paulo: Saraiva, 2003. v. 7.

VENOSA, Sílvio de Salvo. Código Civil interpretado. 4. ed. São Paulo: Atlas, 2019.

WAAL, Marius J. de. Comparative succession law. In: REIMANN, Mathias; ZIMMERMANN, Reinhard (orgs.). The Oxford Handbook of Comparative Law. Oxford: Oxford University Press, 2006.

WOLF, Manfred; WELLENHOFER, Marina. Sachenrecht. 34. ed. München: C.H. Beck, 2019. 